\title{
Application of Circular Economy in Shrinking
}

\section{Regions}

\author{
Agita Livina \\ Vidzeme University of Applied \\ Sciences \\ agita.livina@va.lv
}

\author{
Linda Veliverronena \\ Vidzeme University of Applied \\ Sciences \\ linda.veliverronena@va.lv
}

\begin{abstract}
Shrinking of rural regions is going on in Eastern and Western European countries. Shrinking phenomena includes Latvia, Lithuania, Estonia and other countries and regions. The shrinking region is considered as untoward and gone territory for economic growth particularly from the perspective of policy makers. Shrinking region requires specific tools for development. The aim of this study is to analyse theoretical options for circular economy development in shrinking regions. The growth economy which requires planning more and more profit, units of goods, jobs etc. is not an adequate strategy for shrinking regions. The desktop approach is applied by analysing research articles on shrinking phenomena and circular economy with aim to explore the potential benefits provided by application of principles of circular economy in shrinking regions. The study also reviews policy planning documents on circular economy and regional development at the European Union level and specifically in Latvia which has lost dramatic proportion of inhabitants in last few decades.

The findings of the study show that at first, national policy and EU policy does not accept the phenomena of shrinking regions; second, principles of circular economy are applicable to shrinking regions. There are such challenges as cooperation, philosophy of consumption and values, willingness and availability to pay for services. The study will open a discussion about shrinking rural regions and circular economy from another perspective because until now circular economy is mostly related with the zero waste concept.
\end{abstract}

Keywords - circular economy, shrinking rural region, planning, balanced development.

\section{INTRODUCTION}

Low population density is one of the characteristics common to European rural areas [1], [13] and rural regions currently account for $28 \%$ of Europe's population [5] also population shrinking is actual in economically well developed country as Japan [22], [15] and in fast growing China. As the number of residents is shrinking, including by ageing, density of the population is reducing more distinctly in rural territories where it is necessary to look for other development directions as opposed to the growth strategy. In general, the shrinking as such is not a new concept; however, urban shrinking has been studied more [26], but less attention has been paid to studies of this aspect in rural territories [28], [30]. European Union programme ESPON considers rural shrinkage as $a$ demographic and economic phenomenon and refers to it as "part of wider trends in European territorial restructuring, where agriculture has become less labour intensive and economic and employment growth has become progressively tertiarised, favouring larger urban centres". [5]. Thus shrinking of rural regions is a result of structural complex changes brought on by interrelated factors, including globalisation and coping with it requires new approaches to planning [30]. At the same time, we can note that the world as a whole is experiencing continuous population increase and economic growth, while overall the world's natural ecosystem is shrinking by size and volume [18].

In this article we will look at shrinking rural areas from such an angle that shrinkage in regions mainly is connected with a dramatic population decline, but there are also other challenges such as jobs, service provision, vacancy of buildings, downgrading of public transport, deterioration of the quality of the environment, not many alternative industries growing, maintenance of infrastructure, social problems longer travelling distance to services [25], [26], [28], [33]. In a shrinking region GDP per capita is lower, there is also higher unemployment rate, population ageing, interregional state aid transfers, loss of creative and innovative talents and the capacity to react to change [6], therefore it is not surprising that shrinking of rural regions and shrinking in general is automatically considered a failure and associated with low quality of living. It is necessary to see new opportunities, new economy to cope with this phenomena [26], [28], [32], [13]. Muller and Siedentop shows decline oriented planning characteristics that include recycling of land and buildings, qualitative development, cost efficient stock development, reconversion, small scale functional mix and taking account of life cycle of facilities and demographic changes etc. [25].

This study approaches to shrinkage as potential positive opportunity and identifies circular economy as an alternative way to cope with shrinking by reviewing previous studies and development planning documents. Also, studies on circular economy are more often related with development in an urban environment, and therefore the research paper binds together these two concepts with an aim to analyse the potential of application of circular

Print ISSN 1691-5402

Online ISSN 2256-070X

http://dx.doi.org/10.17770/etr2019vol1.4196

(C) 2019 Agita Livina, Linda Veliverronena. Published by Rezekne Academy of Technologies. 
economy principles in the shrinking rural regions. According to Eurostat (2018) Latvia is among the top three countries experiencing the greatest population decline in the Europe, therefore development planning documents in Latvia will be placed under specific scrutiny.

A term integrated rural development focuses on modern comprehension of endogenous model by emphasizing the perceived need to break down barriers in sectorial policy among economics, society and environment at the local level. Integrated rural development contains three principles as integration, individuality, involvement. From circular economic point of view, it is significant to reach integration between sectorial policies for harmonising economical, social and environmental goals [1].

Latvia's population on March 1, 2011, in accordance with the 2011 Population and Housing Census data was 2,070,371. Since the previous Population and Housing Census 2000 the population has decreased by $13 \%$. Before and including the Population and Housing Census 1989, the number of population has been growing rapidly. During the period between Census 1935 and Census 1989, the population of Latvia increased by almost $40 \%$. The urban population in this period increased 2.7 times, while the rural population decreased by $35 \%$. Since 1990 , both the total population of the country, as well as urban and rural population has been declining [2].

Since the 1990s, Lithuania lost almost one-quarter of its population, and some regions within the country lost more than $50 \%$ of their residents caused by large-scale emigration, natural population decline and changing residential mobility patterns. According to United Nations (as cited in Ubarevičienè \& van Ham, 2017), it ranks Lithuania among countries with the greatest population decline in the world. Between 2000 and 2010 in Lithuania, the population decline was $-10.4 \%$ [36].

Researchers courageously write about shrinking regions in shrinking country in Lithuania by putting this phrase in the title of a research article in a scientific discussion as well as in policy making meetings, while in Latvia quite a few avoids to use such phrases as a shrinking region or shrinkage [28] however, Latvian situation is not unique as ESPON (2017) states that idea of accepting decline is often politically unpalatable. Ubarevičienè et. al mentioned that in Lithuania most of the regional planning is still growth-oriented in spite of the population decline. In the concluding part of Ubarevičaine's article, attention has been drawn to the situation that there are no elaborated long-term strategies for adaptation of shrinkage [35]. In declining areas, the most efficient strategy would be to accept a decline and concentrate services in the accessible regional centres.

Portuguese researchers suggest specific approaches, strategies and recommendations to deal with shrinkage: vacant properties and land banks, housing and integrated regeneration, de-suburbanisation and social capitalisation, regional, technical infrastructure, transportation and finance [34].
The report "The Impact of demographic changes on European regions" initiates alternative forms of production of services and options to improve economic development perspectives. Gløersen et.al (2016) offers to use silver economy, volunteering, residential economy, remittances and self-perception and branding for fiscal sustainability in regions and localities [11].

Paula (2016) analyses theoretical models for rural development by grouping them in two categories: exogenous and endogenous development models. Margarian criticises endogen development approach which is used in European Union for rural development [21], [27]. Ray (2001) introduced term neoendogeonous model where external factors are crucial for rural development, but at the same time it is indicated that local territory has a potential to advance its development [29].

The authors stress the significance of shrinking of rural areas and continue the string of studies exploring alternative ways how to cope with this phenomena, in this case, by focusing to the possibilities provided by circular economy.

\section{METHODS}

Desktop research methodology consisted of several steps: first literature review on circular economy and shrinking regions were implemented by conducting analysis in the Web of Science core collection database and Google research engine by the searching topics "shrinking rural region", "circular economy for regions" in timeline from 1998 to 2019 February. It was followed by identification of related policy planning documents and reports at European Union level (9 documents) and as case example at national level in Latvia (3) suggesting application of circular economy practices in the context of development of rural territories. Finally, authors identified several principles of circular economy that can be applied to cope with shrinkage in rural territories.

\section{CiRCULAR ECONOMY IN THE CONTEXT OF RURAL} SHRINKING

The European Parliament study shows the typology of "shrinking regions" 2005-2030 into four categories. We will focus on the countries whose examples and studies have been used in the present article. Latvia and Estonia have been put into category "certainly decreasing", Lithuania into "probably decreasing", Portugal into "probably decreasing" and a few other regions into "probably increasing" (growing regions). According to EU statistics the most significant population shrink per 1000 people in 2018 was in Lithuania, Croatia and Latvia [9]. Pužulis\&Kūle argue that in Latvia and other places in Europe, the he policy planning documents do not respond to phenomenon of shrinking rural regions adequately. Shrinkage requires planning for a smaller amount at a higher quality [12], [28]. Table 1 demonstrates findings of policy planning documents regarding shrinkage and circular economy approach in EU and Latvia. 
Environment. Technology. Resources. Rezekne, Latvia Proceedings of the 12th International Scientific and Practical Conference. Volume I, 147-153

TABLE 1 REVIEW OF POLICY PLANNING DOCUMENTS AND STUDY REPORTS ON SHRINKING REGIONS AND CIRCULAR ECONOMY

\begin{tabular}{|c|c|c|c|}
\hline Year & $\begin{array}{l}\text { Tittle of policy } \\
\text { planning document, } \\
\text { report }\end{array}$ & $\begin{array}{l}\text { Mention of re- } \\
\text { gions shrinkage }\end{array}$ & $\begin{array}{l}\text { Mention of circu- } \\
\text { lar economy }\end{array}$ \\
\hline 2017 & $\begin{array}{l}\text { Shrinking regions } \\
\text { and innova- } \\
\text { tive solutions: } \\
\text { entrepreneurship, } \\
\text { employment and } \\
\text { the accessibility } \\
\text { of services. Study } \\
\text { report. }\end{array}$ & $\begin{array}{l}\text { Shrinking } \\
\text { regions }\end{array}$ & $\begin{array}{c}\text { Co-design } \\
\text { service } \\
\text { Product innova- } \\
\text { tions (integrated } \\
\text { social care and } \\
\text { health) }\end{array}$ \\
\hline 2017 & $\begin{array}{l}\text { Report of the } \\
\text { implementation } \\
\text { of the Circular } \\
\text { Economy Action } \\
\text { Plan. (European } \\
\text { Commission) }\end{array}$ & none & $\begin{array}{c}\text { Changes in legis- } \\
\text { lation to increase } \\
\text { validity term of } 2 \\
\text { years for goods, } \\
\text { Ecodesign, Food } \\
\text { waste, } \\
\text { Secondary mar- } \\
\text { ket operations, } \\
\text { Green public } \\
\text { procurement, } \\
\text { Construction\& } \\
\text { demolition }\end{array}$ \\
\hline 2017 & $\begin{array}{l}\text { Shrinking rural } \\
\text { regions in Europe: } \\
\text { Towards smart } \\
\text { and innovative } \\
\text { approaches to } \\
\text { regional develop- } \\
\text { ment challenges in } \\
\text { depopulating rural } \\
\text { regions. Policy } \\
\text { brief. }\end{array}$ & $\begin{array}{l}\text { Shrinking } \\
\text { rural regions, } \\
\text { depopulation }\end{array}$ & $\begin{array}{l}\text { Fostering } \\
\text { ecosystem } \\
\text { services and the } \\
\text { green economy } \\
\text { through circular } \\
\text { economy }\end{array}$ \\
\hline 2016 & $\begin{array}{l}\text { The impact of de- } \\
\text { mographic change } \\
\text { on European } \\
\text { regions }\end{array}$ & $\begin{array}{c}\text { Ageing, } \\
\text { population } \\
\text { shrinkage at } \\
\text { regional level }\end{array}$ & $\begin{array}{l}\text { Income circu- } \\
\text { lation between } \\
\text { regions and } \\
\text { localities, resi- } \\
\text { dential economy, } \\
\text { volunteering }\end{array}$ \\
\hline 2016 & $\begin{array}{l}\text { EIO Bi-annual } \\
\text { report } 2016 \text { "Poli- } \\
\text { cies and Practices } \\
\text { for Eco-Innova- } \\
\text { tion Up-take and } \\
\text { Circular Economy } \\
\text { Transition" }\end{array}$ & $\begin{array}{l}\text { Local govern- } \\
\text { ments }\end{array}$ & $\begin{array}{l}\text { Re-use, sharing, } \\
\text { collaborative } \\
\text { consumption, } \\
\text { repair, user-led } \\
\text { eco-design, } \\
\text { material loops, } \\
\text { resource effi- } \\
\text { ciency }\end{array}$ \\
\hline 2014 & $\begin{array}{l}\text { Rural Development } \\
\text { Programme of } \\
\text { Latvia 2014-2020 }\end{array}$ & None & $\begin{array}{l}\text { Rural develop- } \\
\text { ment includes } \\
\text { activities with } \\
\text { environmentally } \\
\text { friendly manage- } \\
\text { ment methods }\end{array}$ \\
\hline 2013 & $\begin{array}{l}\text { Common Agricul- } \\
\text { tural Policy 2014- } \\
2002 \text { (European } \\
\text { Commission) }\end{array}$ & $\begin{array}{l}\text { Challenges of } \\
\text { areas touched } \\
\text { by demogra- } \\
\text { phy, economy } \\
\text { and social } \\
\text { issues } \\
\text { Support for } \\
\text { competitive- } \\
\text { ness in all } \\
\text { regions }\end{array}$ & $\begin{array}{c}\text { Food security, } \\
\text { organizing of } \\
\text { food chain, re- } \\
\text { source efficiency, } \\
\text { quality of soils, } \\
\text { water; } \\
\text { Support and } \\
\text { promotion of } \\
\text { agricultural, } \\
\text { forestry and } \\
\text { food production } \\
\text { activities which } \\
\text { direct to climate } \\
\text { change friendly } \\
\text { management }\end{array}$ \\
\hline
\end{tabular}

\begin{tabular}{|c|c|c|c|}
\hline Year & $\begin{array}{l}\text { Tittle of policy } \\
\text { planning document, } \\
\text { report }\end{array}$ & $\begin{array}{l}\text { Mention of re- } \\
\text { gions shrinkage }\end{array}$ & $\begin{array}{l}\text { Mention of circu- } \\
\text { lar economy }\end{array}$ \\
\hline 2012 & $\begin{array}{l}\text { National Develop- } \\
\text { ment Plan of Lat- } \\
\text { via for 2014-2020 }\end{array}$ & $\begin{array}{l}\text { Markets are } \\
\text { shrinking } \\
\text { (paragraph } \\
66 \text { ); } \\
\text { Stability for } \\
\text { Demographic } \\
\text { Growth; } \\
\text { Decline of } \\
\text { population in } \\
\text { regions }\end{array}$ & $\begin{array}{l}\text { Waste separa- } \\
\text { tion, recycling, } \\
\text { Green public } \\
\text { procurement }\end{array}$ \\
\hline 2010 & $\begin{array}{l}\text { Sustainable Devel- } \\
\text { opment Strategy of } \\
\text { Latvia until } 2030\end{array}$ & $\begin{array}{l}\text { "Intelligent } \\
\text { shrinking" } \\
\text { Silver econ- } \\
\text { omy }\end{array}$ & $\begin{array}{c}\text { "Green econo- } \\
\text { my" } \\
\text { Eco-efficient } \\
\text { economy }\end{array}$ \\
\hline 2010 & $\begin{array}{c}\text { The EU } 2020 \\
\text { strategy }\end{array}$ & Ageing & $\begin{array}{c}\text { Sustainable } \\
\text { growth, greener } \\
\text { economy, } \\
\text { resource efficient } \\
\text { Europe }\end{array}$ \\
\hline 2008 & $\begin{array}{l}\text { Shrinking Regions: } \\
\text { a Paradigm Shift in } \\
\text { Demography and } \\
\text { Territorial Devel- } \\
\text { opment. Study. } \\
\text { European Parlia- } \\
\text { ment, 2008. Direc- } \\
\text { torate-General for } \\
\text { internal Policies of } \\
\text { the Union. }\end{array}$ & $\begin{array}{l}\text { Shrinking } \\
\text { region }\end{array}$ & $\begin{array}{l}\text { The chances } \\
\text { of new and } \\
\text { attractive } \\
\text { economic zones } \\
\text { developing; } \\
\text { Mobile services }\end{array}$ \\
\hline 2001 & $\begin{array}{l}\text { Report The Nature } \\
\text { of Rural Develop- } \\
\text { ment: Towards a } \\
\text { Sustainable Inte- } \\
\text { grated Rural Policy } \\
\text { in Europe }\end{array}$ & $\begin{array}{l}\text { Remote rural } \\
\text { areas } \\
\text { Attractive pe- } \\
\text { ripheral areas } \\
\text { Less favored } \\
\text { area }\end{array}$ & $\begin{array}{l}\text { Good manage- } \\
\text { ment of the } \\
\text { environment } \\
\text { Integration } \\
\text { across sectors }\end{array}$ \\
\hline
\end{tabular}

The National Development Plan (NDP) of Latvia for 2014-2020 has set three priorities: growth of the national economy, human securitability and growth of the regions. It has been stated in the planning document that the economy expands and Latvian regions are thriving (paragraph 52). The NDP is aimed at a growth model (paragraph 367). In order to stem these negative trends, it is necessary to increase economic activity in the regions and development centres by attracting and using the resources of the surrounding territories, encouraging the development of business activity and the transport and ICT infrastructure, developing and fully utilising the potential of educational institutions and boosting people's mobility. This would facilitate the creation of new businesses and jobs, providing an impetus for living and working in the regions. Cross-border international cooperation that provides greater opportunities for implementing strategic development projects is an important precondition for the regional development [3].

The EIO Bi-annual report 2016 "Policies and Practices for Eco-Innovation Up-take and Circular Economy Transition" shows that Latvia had the highest proportion of people $(3,18)$ employed in selected recycling, repair and reuse sector per 1,000 inhabitants in 2014 among EU member states. The situation is radically different in relation to the turnover per 1,000 employees in the circular economic sectors. Researches name such factors as lack of skills and knowledge, social capital in 
shrinkage regions [4].

Sepp and Vaamee found in a case study of Austria that regions with population decline are not automatically regions with work economic performance or low quality of life [32]. In case of Latvia, the government is concentrating services in the largest cities and in regional centres, but it brings to related problems that promote shrinking in Latvian regions. Pužulis un Kūle (2016) point at consequences of such policies, naming closure of schools as an example - in these cases loss to the local municipalities grows fourfold because teachers lose jobs, tax payments into the local governments' budget decrease, more financing will be transferred to the neighboring municipalities and there will be more expenses for transportation of pupils [28]. However, it is significant to emphasise that transport expenses and payments to other municipalities are hardly the only loses. School closure is frequently followed by cancellation of regular bus service, closed enterprises and increased flow of emigration. As a result, people from such places move to other areas, transport expenses grow, including for the local government to transport pupils to schools, the social capital that is needed to find new development opportunities in rural employment, self-employment, creation of services and export in the territory is shrinking [19].

Pužulis\&Kūle (2016) mark further issues of study of shrinking rural regions, such as: What services are needed and how are they being provided? What settlement models can be proposed for shrinking areas?

The circular economy is increasingly debated on the agenda of the European Union, as well as several of Member States follow the calculation of circular economic benefits and it is included in their policy planning documents [17], [18]. Kalmykova et.al has analysed 118 documents from which 17 refers to circular policy. Universities follow the idea of circular economy and introduce it into their training programmes. One of the courses of the interhigh-school intensive study programme took place in March 2019 in Latvia, the University of Liepāja, which was implemented by partners from Finland, Estonia, Lithuania and Latvia.

Sepp and Veemaa (2017) indicate five activities for improving accessibility of services and responding to shrinking with new services: innovative mobility solutions, broadband ICT and Internet based e-solutions, delivery outlet solutions, co-design and co-delivery of services and new services responding to and capitalising on shrinking and ageing processes [32]. The concept of service co-design contributes in the circular economy context, at least as collaboration among different partners, researchers, designers, customers, potential customers and users. Circular economy approach is illustrated in product innovation by integrating social care and health services. Thus, these proposals on availability of services in the shrinking regions show on such circular economy component as sharing and sharing and cooperation in governance. The sharing economy is an opportunity for a circular economy that ensures sustainable development is identified in the studies of a number of researchers [16], Korhonen et.al (2018) note that the shrinking process is a complex issue that includes many parties (local municipalities, schools, NGO, private sector, clusters, inhabitants etc.). [18] Importance of society engagement in development processes is indicated by Vaeliverronen et al. (2017) stating that municipalities would gain if they invested more effort into creating a system to intensify community engagement instead of isolated projectbased activities [37]. In order for the circular economy to operate successfully, the stakeholders should cooperate closely. Stahel argues that a circular economy builds on self-responsibility of economic actors and higher competitiveness through more efficient free market solutions, technical and commercial innovation [10]. Mobility solutions in shrinking and remote areas show that locals are using self-organising activities to find ways for mobility. In carried out interviews, we found that $79 \%$ of respondents to interviews are using ride-share mobility. Other option is transport on demand which is implemented in several remote rural areas in Germany, Finland etc. instead of regular public transport by saving resources and environment.

Franconi et. al (2016) name three key factors for circular business models: resource use, service lifetime, and economic value creation. The good match is when service lifetime is higher and economic value is higher [10]. Stahel indicates a statement that policy makers and economic actors of the manufacturing economy do not know principles of circular economy, nor their impact on the economy. Confirmation for this statement is made in report of Latvian rural spatial development (2012) by analyzing statistical data by sectors in rural municipalities, excluding municipalities in Pierīga statistical region): $63 \%$ of economically active units deal with agriculture, forestry and fishery; $28 \%$ in service industries, $5 \%$ in manufacturing industry, $2 \%$ in building and $2 \%$ in other [33]. Analyses of rural development areas as system (e.g. Paula, 2016) claim that traditional agriculture mainly dominates in rural policy planning documents; however, a consumption of bio products is increasing in the world. For example, there is conducted research about the role of psychological determinants for organic consumerism in Australia [23]. Taking into account the trend of bio product consumption, bio farming should be considered as an alternative economic development opportunity for shrinking rural areas.

\section{RESUlTS AND DISCUSSIONS}

On the basis if previous studies and analysis if regional planning documents, application of solutions in solving the problems of shrinking rural regions based on circular economy principles and elements are identified in Table 2. Five groups of challenges faced by shrinking rural regions have been analysed (mobility, vacancy of buildings, waste collection\&recycling, service location, bio agriculture), offering the ideas how to apply circular economy principles in shrinking areas. 
The circular economy in shrinking rural areas has the biggest potential to contribute to social field by integrating new mobility solutions such as ride sharing, renting rooms or houses for visitors in short term or in long term for living. The challenging precondition for sharing economy is established close cooperation among people in and outside the community. New workplaces are created, restructuring existing jobs with a new use of unused resources.

The main benefits in the circular economy in rural areas would be new markets for previously unused, usage of recycled resources for creation new products. Free resources can be leased, offered for rent, thus reducing potential start-up costs, and making a place more attractive to other entrants, including entrepreneurs. Successful business examples attract young people, entrepreneurs, who make the site attractive to both local residents and guests.

The components of the circular economy in the shrinking regions contribute to waste reduction, composting and to the smart use of water resources in the natural environment.

One of the challenges faced by shrinking rural territories are increased costs for servicing and maintaining infrastructure. In this context, the opportunities provided by circular economy to save resources and consequently costs, should be emphasized.

TABle 2 ApPlicAtion OF CIRCULAR ECONOMY APPROACH TO RURAL SHRINKING REGIONS

\begin{tabular}{|c|c|c|}
\hline $\begin{array}{l}\text { Principle, element of } \\
\text { circular economy }\end{array}$ & $\begin{array}{l}\text { Problem in rural } \\
\text { shrinking region }\end{array}$ & Application \\
\hline $\begin{array}{l}\text { To increase level } \\
\text { of efficiency of } \\
\text { goods, less con- } \\
\text { sumption } \\
\text { Resource sharing } \\
\text { principle }\end{array}$ & $\begin{array}{l}\text { Mobility for peo- } \\
\text { ple to services, } \\
\text { work, recreation, } \\
\text { lifelong learning } \\
\text { etc.: } \\
\text { · Limited } \\
\text { options of public } \\
\text { transport; } \\
\text { - Restriction } \\
\text { to use School } \\
\text { bus for non-stu- } \\
\text { dents. }\end{array}$ & $\begin{array}{l}\text { At the moment } \\
\text { mobility as ride-sharing } \\
\text { (communicating by } \\
\text { call, social media etc.) } \\
\text { and self-organisation } \\
\text { of mobility options } \\
\text { exist. Self-organisation } \\
\text { is viable approach } \\
\text { without any additional } \\
\text { resources. } \\
\text { There is an option } \\
\text { for changes to use } \\
\text { efficiency of School } \\
\text { buses in rural regions } \\
\text { by allowing School bus } \\
\text { service for others. In } \\
\text { case of Latvia, mobility } \\
\text { is paid twice by public } \\
\text { taxes for the same } \\
\text { reason at the same time }\end{array}$ \\
\hline $\begin{array}{l}\text { Resource sharing } \\
\text { principle }\end{array}$ & $\begin{array}{l}\text { Vacancy of } \\
\text { buildings: } \\
\text { · Empty } \\
\text { houses, build- } \\
\text { ings; } \\
\text { - Second } \\
\text { homes. }\end{array}$ & $\begin{array}{l}\text { Long-term rent, short- } \\
\text { term rent for temporary } \\
\text { workers, visitors. } \\
\text { Option is to organise } \\
\text { community-based NGO } \\
\text { who is dealing with } \\
\text { rent. }\end{array}$ \\
\hline
\end{tabular}

\begin{tabular}{|c|c|c|}
\hline $\begin{array}{l}\text { Principle, element of } \\
\text { circular economy }\end{array}$ & $\begin{array}{l}\text { Problem in rural } \\
\text { shrinking region }\end{array}$ & Application \\
\hline $\begin{array}{l}\text { Zero waste } \\
\text { strategy }\end{array}$ & $\begin{array}{l}\text { Free and unused } \\
\text { resources } \\
\text { Recycling bins } \\
\text { far away from } \\
\text { residential } \\
\text { houses. } \\
\text { Less waste in } \\
\text { rural areas: } \\
\text { - Composting } \\
(+) \text {; } \\
\text { - Burning of } \\
\text { waste (-). }\end{array}$ & $\begin{array}{l}\text { Used for new products, } \\
\text { services as well as } \\
\text { nature for inspirations } \\
\text { of new designs } \\
\text { Using bio composting } \\
\text { Waste bags for } \\
\text { recycling (free of } \\
\text { charge) } \\
\text { Use of food waste for } \\
\text { animal feed }\end{array}$ \\
\hline $\begin{array}{l}\text { To reduce foot car- } \\
\text { bon emissions and } \\
\text { to decrease food } \\
\text { waste }\end{array}$ & $\begin{array}{l}\text { Services are } \\
\text { located in larger } \\
\text { urban areas: } \\
\text { P People } \\
\text { need to } \\
\text { travel } \\
\text { longer dis- } \\
\text { tance for } \\
\text { shopping; } \\
\text { Buy more } \\
\text { than necessary at } \\
\text { present. }\end{array}$ & $\begin{array}{l}\text { Business is providing } \\
\text { mobile retail shops in } \\
\text { remote areas (service to } \\
\text { people). } \\
\text { Goods are } \\
\text { expensive, less } \\
\text { preferences; } \\
\text {. } \quad \text { Limited social- } \\
\text { izing. } \\
\text { Travelling to shop } \\
\text { longer distances, but } \\
\text { seldom: } \\
\text { B } \\
\text { Buy more than } \\
\text { necessary } ® \text { use } \\
\text { as food for chick- } \\
\text { en, pigs, rabbits; } \\
\text { More extra time } \\
\text { and fuel spent. Option } \\
\text { to use online shopping } \\
\text { of biggest merchants, } \\
\text { but delivery is more } \\
\text { expensive in rural } \\
\text { areas. Online shopping } \\
\text { excludes socialising. }\end{array}$ \\
\hline $\begin{array}{l}\text { Organic farming } \\
\text { in whole product } \\
\text { chain }\end{array}$ & $\begin{array}{l}\text { Organic agri- } \\
\text { culture options } \\
\text { instead of tradi- } \\
\text { tional agriculture }\end{array}$ & $\begin{array}{l}\text { There is potential to } \\
\text { deal with organic agri- } \\
\text { cultural production. } \\
\text { Market growth for } \\
\text { organic products ( }+) \\
\text { Rural area is added } \\
\text { value for marketing, if } \\
\text { it is not industrial and } \\
\text { does not pollute the } \\
\text { area (+) } \\
\text { Far away from the mar- } \\
\text { ket, includes expenses } \\
\text { of fuel, time, quality } \\
\text { of roads for fresh fruit } \\
\text { etc. }(-)\end{array}$ \\
\hline
\end{tabular}

\section{Conclusions}

1.The application of circular economy principles provides an opportunity to decrease rising costs of services and infrastructure maintenance in shrinking regions.

2. Findings of the conducted literature review show that there is an opportunity to apply principles of circular economy in shrinking rural regions. The policy planning documents increasingly recognizes the shrinking regions recently; however, inappropriate instruments 
for development of these regions are proposed, mostly applying the growth development strategy principles as confirmed by several study reports from different countries and policy planning documents at the EU level. Shrinking rural regions are a challenge to policy makers, requiring close cooperation and integration among sectors and stakeholders of all levels, as it has been confirmed by Hospers (2014).

3. Cooperation is the basis of successful functioning of circular economy. At present, separate circular economy principles are applied in the shrinking regions, for example, unofficial, self-organised ride-sharing service which is developed in a situation when there are no other solutions, namely, in a crisis situation, to ensure mobility. Thus, to strengthen the potential of circular economy in shrinking territories, municipalities should initiate and support activities strengthening local community and grassroot initiatives.

4. This study is based on desktop approach and provides novel, although rather general connections between shrinking regions and circular economy. It identifies the potential of circular economy to contribute shrinking economy; however, applied field studies in shrinking territories would be needed to design more elaborate solutions.

5. The development of circular economy in shrinking territories is related with a need to welcome new motivated entrants in shrinking territories which is not typical. Strategic support from both local and national government to initiatives that have potential to attract specific type of stakeholders to live or work in shrinking territories is one of the crucial preconditions to initiate and strengthen practices of circular economy in shrinking territories.

\section{REFERENCES}

[1] Baldock, D., Dwyer, J., Lowe, P., Petersen, J.E.\&Ward, N. 2001. Report The Nature of Rural Development: Towards a Sustainable Integrated Rural Policy in Europe. A Ten-Nation Scoping for WWF and the GB Countryside Agencies. [Online] Available at: IEEP http://minisites.ieep.eu/assets/78/natureruraldevelopment. pdf [Accessed 16 March 2018].

[2] Central Statistical Bureau of Latvia, 2015. Results of the 2011 Population and Housing Census in Latvia, Riga: Central Statistical Bureau of Latvia.

[3] Cross-Sectoral Coordination Centre (CSCC). 2012. National Development Plan of Latvia for 2014-2020. Approved by a Decision of the Saeima on 20 December 2012

[4] Doranova, A., Roman, L., Bahn-Walkowiak., Wilts, H., O`Brien, M., Giljun, S., Kong, M.A., Hestin, M. 2016. EIO Bi-annual report 2016 "Policies and Practices for Eco-Innovation Up-take and Circular Economy Transition”. European Commission: Eco-Innovation Observatory.

[5] Epson (2017). Policy Brief. Shrinking rural regions in Europe Towards smart and innovative approaches to regional development challenges in depopulating rural region. European Union. Available at: https://www.espon.eu/sites/default/files/attachments/ ESPON\%20Policy\%20Brief\%20on\%20Shrinking\%20Rural\%20 Regions.pdf

[6] European Comission. 2010. Europe 2020 A strategy for smart, sustainable and inclusive growth. [Online] Available at: http:// ec.europa.eu/eu2020/pdf/COMPLET\%20EN\%20BARROSO $\% 20 \% 20 \% 20007 \% 20-\% 20$ Europe $\% 202020 \% 20-\% 20$ EN\%20 version.pdf [Accessed 16 March 2018].
[7] European Commission. 2013. Common Agricultural Policy 20142002

[8] European Commission. 2017. Report of the implementation of the Circular Economy Action Plan. [Online] Available at: http:// ec.europa.eu/environment/circular-economy/implementation_report.pdf [Accessed 16 March 2018].

[9] EUROSTAT. 2018. EU population up to nearly 513 million on 1 January 2018. Eurostat News release 115/2018. Available at: https://ec.europa.eu/eurostat/documents/2995521/9063738/310072018-BP-EN.pdf/ccdfc838-d909-4fd8-b3f9-db0d65ea457f

[10] Franconi, E., Bridgeland, B., Graichen, P. et.al. 2016. A New Dynamic 2- Effective Systems in a Circular Economy. Ellen MacArthur Foundation.

[11] Gløersen, E., Drăgulin, M., Hans, S., Kaucic, J., Schuh, B., Keringer F., Celotti P. 2016. The impact of demographic change on European regions. European Union Committee of the Regions.

[12] Haase, A., Rink, D., Grossmann, K., Bernt, M., Mykhenko, V. 2014. Conceptualizing urban shrinkage. Environment and Planning A. 46 (7), 1519-1534

[13] Haase, A., Athanasopoulou, A., Rink, D. 2016. Urban shrinkage as an emerging concern for European policymaking. European Urban and Regional Studies 2016, Vol. 23(1) pp. 103-107

[14] Haase, A., Athanasopoulou, A., Rink, D.. 2013.Urban shrinkage as an emerging concern for European policymaking. European Urban and Regional Studies.

[15] Haga, K. 2018. Innovation in rural Japan: entrepreneurs and residents meeting the challenges of aging and shrinking agricultural communitie. Journal of innovation economics \& management. Issue: 25 . pp. 87-117

[16] Hospers, G.J. 2014. Policy Responses to Urban Shrinkage: From Growth Thinking. European Planning Studies 22 (7), pp. 15071523

[17] Kalmykova, Y., Sadagopan, M., Rosado, L. 2018. Circular economy-From review of theories and practices to development of implementation tools. Resources, Conservation\&Recycling 135 (2018) pp.190-201.

[18] Korhonen, J., Honkasalo, A., Seppälä, J. 2018. Circular Economy: The Concept and its Limitations. Ecological Economics. 143 (2018) pp.37-46

[19] Livina, A., Rozentale, S., Bikse, J. 2018. Report Pre-study concerning the economic framework for innovative rural mobility solutions. EU MAMBA project.

[20] Lovins, A.B., Franconi, E., Bridgeland, B., Graichen, P. et.al. 2013. A New Dynamic Effective Business in a Circular Economy 1. Ed. Webster, K., Jocelyn, B., Johnson

[21] Margarian, A. 2013. A Constructive Critique of the Endogenous Development Approach in the European Support of Rural Areas. Growth and Change, 44(1), 1-29. [Online] Available at: http:// dx.doi.org/10.1111/grow.12000 [Accessed 16 March 2018].

[22] Matanle, P. (2010) Introduction: A special focus on shrinking regions, Social Science Japan Journal, 13 (2): 183-185.

[23] Miles H.Johe, Navjot Bhullar. 2016. To buy or not to buy: The roles of self-identity, attitudes, perceived behavioral control and norms in organic consumerism. Ecological Economics 128 (2016)99-105.

[24] Ministry of Agriculture of Latvia. 2018. Rural Development Programme of Latvia 2014-2020. [Online] Available at: https:// www.zm.gov.lv/zemkopibas-ministrija/statiskas-lapas/latvijas-lauku-attistibas-programma-2014-2020-gadam?id=14234\#jump [Accessed 25 March 2018].

[25] Müller, B., Siedentop, S. 2004. Growth and Shrinkage in Germany - Trends, Perspectives and Challenges for Spatial Planning and Development. https://difu.de/publikationen/growth-and-shrinkage-in-germany-trends-perspectives-and.html

[26] Pallagst, K., Wiechmann,T., Martinez-Fernandez, C.(eds). 2017. Shrinking Cities: International Perspectives and Policy Implications. Abingdon: Routledge.

[27] Paula, L. 2016. Promocijas darbs: Kopienu rīcībspēja lauku attīstībā Latvijā/ Capability of communities for rural development in Latvi a [Online] Available at: https://www.szf.lu.lv/fileadmin/ user upload/szf faili/Petnieciba/promocijas darbi/Promocijas darbs_Liga_Paula_2016_gala.pdf [Accessed 25 March 2018].

[28] Pužulis, A., Kūle, L. 2016. Shrinking of Rural Territories in Latvia. European Integration Studies. EIS10/2016

[29] Ray, C. (2001). Culture economies. Centre for Rural Econo- 
Environment. Technology. Resources. Rezekne, Latvia Proceedings of the 12th International Scientific and Practical Conference. Volume I, 147-153

my, Newcastle University. [Online] Available at: http://www. ncl.ac.uk/media/wwwnclacuk/centreforruraleconomy/files/culture-economy.pdf_[Accessed 16 March 2018].

[30] Richardson, H.W., Nam, C.W. 2014. Shrinking Cities: A Global Perspective. Abingdon: Routledge.

[31] Saeima of the Republic of Latvia. 2010. Sustainable Development Strategy of Latvia until 2030. Riga: Saeima of the Republic of Latvia

[32] Sepp, V., Veemaa, J. 2017. Shrinking regions and innovative solutions: entrepreneurship, employment and the accessibility of services. Study report. Tartu Ulikool Rake.

[33] SiA Latvijas lauku konsultāciju un izglītības centrs (LLKIC). 2012. Latvijas lauku telpas attīstība un tās iespējamie nākotnes scenāriji/Development of Latvia's rural environment and its possible future scenarios. [Online] Available at: http://www.laukutikls.lv/biblioteka/cat_view/134-lauksaimnieciba_un_lauku_attistiba [Accessed 16 March 2018].
[34] Sousa, S., Pinho, P. 2014. Shrinkage in Portuguese National Policy and Regional Spatial Plans: Concern or Unspoken Word? Journal of Spatial and Organizational Dynamics, CIEO-Research Centre for Spatial and Organizational Dynamics, University of Algarve, vol. 2(4), pp. 260-275.

[35] Ubarevičienė, R., Ham van M., Burneika, D. 2016. Shrinking Regions in a Shrinking Country: The Geography of Population Decline in Lithuania 2001-2011. Urban Studies Research, Volume 2016 (2016)

[36] Ubarevičienė, R., van Ham,M. 2017. Population decline in Lithuania: who lives in declining regions and who leaves? Regional Studies, Regional Science, Vol. 4(1), 57-79.

[37] Vaeliverronen, L., Kruzmetra, Z., Livina, A., Grinfelde, I. 2017. Engagement of Local Communities in Conservation of Cultural Heritage in Depopulated Rural Areas in Latvia. International Journal of Cultural Heritage, 2, 13-21. IARAS Pub. 